\title{
Physico-chemical, mechanical and histological characteristics on rumen and reticulum of sheep submitted to different techniques of retanning
}

\author{
[Características físico-químicas, mecânicas e histológicas no rúmen e retículo de ovinos \\ submetidos a diferentes técnicas de recurtimento]
}

\section{"Artigo Científico/Scientific Article"}

\author{
Daniel de Almeida Cerquetani ${ }^{1}$, Maria Luiza Rodrigues de Souza ${ }^{1}$, Eliane Gasparino ${ }^{1}$, \\ Doroty Mesquita Dourado ${ }^{2}$, Stefania Caroline Claudino da Silva ${ }^{3}$, Gabriel Roldi ${ }^{3}$, \\ Graciela Lucca Braccini ${ }^{3}$, Bruno Lala ${ }^{4}$
}

\author{
${ }^{1}$ Department of Animal Science, UEM, State University of Maringá, Maringá-PR, Brazil. \\ ${ }^{2}$ Department of Biological, Agricultural and Health Sciences, Universidade para o Desenvolvimento do Estado e da \\ Região do Pantanal, Campo Grande-MS, Brazil. \\ ${ }^{3}$ Program of Master in Science, Technology and Food Safety, Cesumar Institute of Science Technology and Innovation - \\ ICETI. University Center of Mariná, UNICESUMAR, Maringá-PR, Brazil. \\ ${ }^{4}$ Department of Animal Breeding and Nutrition, UNESP, College of Veterinary Medicine and Animal Sciences, São Paulo \\ State University, Botucatu-SP, Brazil. \\ *Autor para correspondência/Corresponding author: E-mail stefaniacaroline@gmail.com
}

\begin{abstract}
The objective was to evaluate the physicochemical, mechanical and histological characteristics on rumen and reticulum of sheep submitted to different retanning techniques. Twenty rumens and reticulum were tanned with chrome and retanned with different tannins (Treatment $1=$ chrome; Treatment $2=$ vegetable; Treatment 3 $=$ synthetic and Treatment $4=$ vegetable + synthetic $)$. Tanned samples of rumens and reticulum were extracted to evaluate the arrangement of fibers, and submitted for determination of chrome oxide, substances extractable with dichloromethane, $\mathrm{pH}$ value and difference figure of aqueous extract. Thickness, traction resistance, elongation and progressive tearing were measured. Retanning with chrome provided greater traction resistance (3.47 $\mathrm{N} \mathrm{mm}-2)$, elongation $(92.76 \%)$ and progressive tearing $(28.81 \mathrm{~N} \mathrm{~mm}-1)$. Retanning with synthetic tannins showed less traction resistance $(2.68 \mathrm{~N} \mathrm{~mm}-2)$ and increased thickness $(1.25 \mathrm{~mm})$. The rumen presented better results for tensile strength and progressive tearing. Elasticity results did not differ for both rumen and reticulum. Both rumen and reticulum retanned with chrome salts showed higher levels of chrome oxide and substances extractable by Dichloromethane (34.2\%). Therefore, the best results were obtained for rumen retanned with chrome salts.
\end{abstract}

Keywords: leather; elasticity; collagen fibers; progressive tearing; traction and elongation.

\begin{abstract}
Resumo
Objetivou-se avaliar as características físico-químicas, mecânicas e histológicas do rúmen e retículo de ovinos submetidos a diferentes técnicas de recurtimento. Vinte rúmens e retículos foram curtidos com cromo e recurtidos com diferentes taninos $($ Trat $1=$ cromo; Trat $2=$ vegetal; Trat $3=$ sintético e Trat $4=$ vegetal + sintético). Amostras recurtidas de rúmen e retículo foram extraídas para avaliar o arranjo das fibras, e submetidas à determinação de óxido de cromo, substâncias extraíveis com diclorometano, valor de pH e cifra diferencial do extrato aquoso. Foram mensurados os valores para espessura, resistência à tração, alongamento e rasgamento progressivo. $\mathrm{O}$ recurtimento com cromo proporcionou maior resistência à tração $\left(3,47 \mathrm{~N} \mathrm{~mm}^{-2}\right)$, alongamento $(92,76 \%)$ e rasgamento progressivo $\left(28,81 \mathrm{~N} \mathrm{~mm}^{-1}\right)$. O recurtimento com taninos sintéticos apresentou menor resistência à tração $\left(2,68 \mathrm{~N} \mathrm{~mm}^{-2}\right)$ e maior espessura $(1,25 \mathrm{~mm})$. $\mathrm{O}$ rúmen apresentou melhores resultados de resistência à tração e ruptura progressiva. Os resultados de elasticidade não diferiram para o rúmen e retículo. Rúmen e retículo recurtidos com sais de cromo apresentaram maiores teores de óxido de cromo e substâncias extraíveis com diclorometano (34,2\%). Portanto, os melhores resultados foram obtidos com o rúmen recurtido com sais de cromo
\end{abstract}

Palavras-chave: couro; elasticidade; fibras colágenas; rasgamento progressivo; tração e alongamento. 


\section{Introduction}

The use of by-products of sheep slaughter still has little economic importance compared to cattle slaughter by-products. However, the interest in processing these products has gradually increased over the past years. Due to increasing costs of slaughter of animals and maintenance of freezers, much of the profit today lies in byproducts and their utilization (Jayathilakan et al., 2012). Meat industry by-products are important not only economically, but also for public health and environmental conservation, since the lack of proper processing of by-products leads to contamination of water and soil. Lamb carcass byproducts constitute from 39.2 to $69.6 \%$ of live animal weight, depending on race, sex, age, body weight, type of birth (single / twin), nutritional status and category of animal and may be a source of many industrial products, thus adding value to secondary products of sheep breeding (Røssvoll, 2018). The use of any animal by-product depends on the generated amount as well as the existence of viable market for turning it into an economically profitable product.

An alternative use of sheep by-products may be tanning parts of stomach, such as rumen and reticulum, depending on the aesthetic aspect after tanning process. Rumen is the largest of prestomach compartments, comprising $80 \%$ of total volume of the stomach, and occupies almost the entire left side of abdominal cavity. In sheep and goats, its capacity is approximately 20 up to 30 liters. Rumen wall is lined by mucosae-covered, slightly flattened papillae, giving it a "fluffy towel" appearance. Rumen is linked to reticulum via the esophageal groove. Reticulum is the smallest of pre-stomachs and its interior is lined by a mucosa, whose relief is similar to that of a honeycomb (Frandson et al., 2005).

Dal Monte (2004) noted that in tanning industries, leather quality is related to chemical, mechanical and aesthetic characteristics. Physicochemical characteristics of leather vary with animal species, conservation techniques and tanning process and are directly related to material that serves as the basis for production. Thus, there is no information regarding the use of rumen and reticulum of sheep in tanning process and more insight is needed as to their strength qualities and their use in clothing industries. Utilization of rumen and reticulum for tanning is quite interesting, and these parts basically serve as raw materials for manufacture of handbags, shoes, coats, pillows and a multitude of other products, as their use largely enhances the appearance and refinement of the final product appearing on the market. The following experiment was conducted in order to determine physicochemical, mechanical and histological characteristics of rumen and reticulum of sheep with the use of different retanning techniques.

\section{Material and Methods}

Rumen and reticulum processing

The tanning process of rumen and reticulum was carried out in the Lab for Processing Skins of Fish and Other Small and Medium Sized Species at the State University of Maringá (FEI-Iguatemi, PR, Brazil South). Twenty rumen and reticulum samples of Dorper + Santa Inês sheep, aged 6-7 months, were used. The rumens and reticulum were obtained as a donation from a local slaughterhouse and stored at $-18{ }^{\circ} \mathrm{C}$ until further processing. They were submitted to tanning process that involved the following steps: pre-soaking, stripping, soaking, liming (with a 3\% lime and 8\% Dermaphel Plus solution), deliming, purging, degreasing, pickling, tanning (with $8 \%$ chrome salts) neutralizing, retanning (different treatments), dyeing, oiling (8\% oils), drying, softening and finishing (a method described by Souza, 2004 and Hoinacki, 1989, with modifications).

To begin the processing, the reticulum and rumens were thawed at room temperature (Figure 1), fleshed and weighed. All samples were treated using the same methodology to minimize errors. In the next step, that involved retanning, they were divided into groups with 5 pieces of rumen and reticulum each, and each group received one type of tanning agent (Treatment $1=4 \%$ chrome salts; Treatment $2=4 \%$ vegetable tannin; Treatment $3=$ $4 \%$ synthetic tannin; Treatment $4=2 \%$ vegetable tannin $+2 \%$ synthetic). Then the samples went through the remaining stages until completion of processing, as mentioned above.

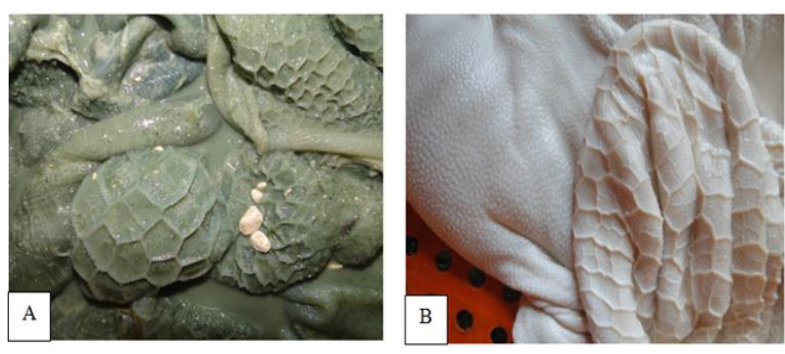

Figure 1. Rumen and reticulum of sheep: (A) before submitting the tanning and (B) after pickling. 
Obtaining samples for physical and mechanical tests

Samples were taken from rumen (Figure 2) and reticulum with the aid of a rocker (ABNT 2005a). Each sample was measured for thickness, strength, traction resistance, elongation (ABNT, 1997a) and progressive tearing (ABNT, 2005b). After that, the samples were taken to an airconditioned environment around $23 \pm 2^{\circ} \mathrm{C}$ and a relative humidity of $50 \pm 5 \%$ for 48 hours (ABNT, 2006a).

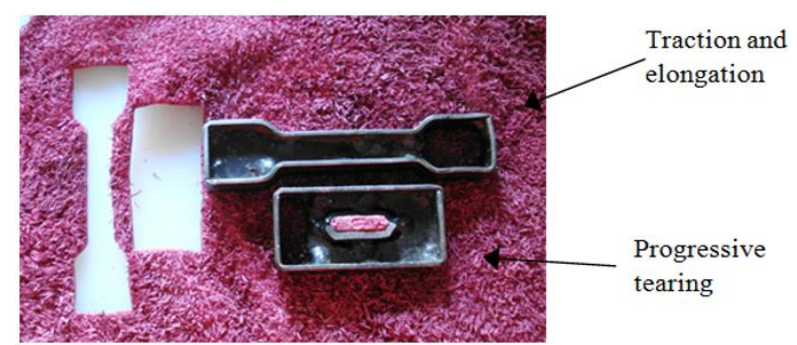

Figure 2. Extract of rumen samples.

For mechanical testing, an EMIC dynamometer was used with a spacing rate between loads of $100 \pm 10 \mathrm{~mm}$ min-1. Load cell used in dynamometer was $200 \mathrm{kgf}$. Calibration was performed by Emic-Dcame, a calibration laboratory accredited by Cgcre/INMETRO under No. 197.

\section{Obtaining samples for chemical tests}

For physicochemical tests, the samples were sent to the laboratory of BASF in Sapucaí do Sul (RS, Brazil South). Chemical analyzes were conducted according to the rules of ABNT (2001). Samples from different treatments of leather were submitted to tests for chrome oxide (Cr2O3) (ABNT, 2007), substances extractable with dichloromethane (CH2Cl2) (ABNT, 1997b), determination of $\mathrm{pH}$ value and difference figure (ABNT, 2006b) of aqueous extract.

Histology samples

Tanned samples, each being $1.0 \times 0.5 \mathrm{~cm}$ in size, were sent for histological analysis in the Research Laboratory of Histopalogy and Molecular Biology at the University AnhangueraUniderp in Campo Grande (MS, Brazil MiddleWest). The samples were subjected to routine histological processing in paraffin and cut 5 micrometer $(\mu \mathrm{M})$ thick. Sections destined for histological analysis were stained with hematoxylin-reaction Picrossirius $(\mathrm{PH})$ and were examined by light microscopy. Slide analysis was done by scanning images via special program for image capture (IMAGELAB) coupled to an Axioplan/Carl Zeiss microscope (Carl Zeiss Inc., GE) and camera.

\section{Experimental design}

Completely randomized design was used in a $4 \times 2$ factorial scheme, with four retanning techniques (Treatment $1=4 \%$ chrome salts; Treatment $2=4 \%$ vegetable tannin; Treatment $3=$ $4 \%$ synthetic tannin; Treatment $4=2 \%$ vegetable tannin $+2 \%$ synthetic) and two regions $(\mathrm{R} 1=$ rumen, $\mathrm{R} 2=$ reticulum) of sample cuts.

The results were submitted to variance analysis using a statistical package (SAEG, 2000), and averages were compared by Tukey test at $5 \%$ probability.

\section{Results}

Rumen and reticulum retanned with synthetic tannin showed greater thickness (1.25 $\mathrm{mm})$, significantly differing from those retanned with synthetic + vegetable tannins and chrome salts. Samples retanned with chrome had lower thickness $(0.85 \mathrm{~mm})$, differing only from those retanned with synthetic tannin. Reticulum $(1,32 \mathrm{~mm})$ showed greater thickness compared to rumen (Table 1).Retanning with vegetable tannin (3.58 N mm-2) and chrome salts $(3.47 \mathrm{~N} \mathrm{mm-2)}$ resulted in higher tensile strength, despite having no significant difference from retanning with synthetic + vegetable tannin (3.19 N mm-2) (Table 1). Rumen (3.61 N mm-2) showed significantly higher tensile strength compared to reticulum (2.52 $\mathrm{N} \mathrm{mm}^{-2}$ ).

Retanning with chrome salts $(92.76 \%)$ increased elongation capability, not differing from retanning with synthetic tannin $(76.06 \%)$ (Table 1$)$. This, on the other hand, did not differ from retanning with vegetable $(68.44 \%)$ and combined tannins (vegetable and synthetic, $68.90 \%$ ). There were no significant differences for stretching between rumen $(74.09 \%)$ and reticulum $(76.78 \%)$.

The use of chrome salts $(28.81 \mathrm{~N} \mathrm{~mm}-1)$ conferred greater resistance to progressive tearing, significantly differing from other treatments. On the other hand, retanning with synthetic tannin provided less resistance to progressive tearing $(16.67 \mathrm{~N} \mathrm{~mm}-1)$, differing significantly from other treatments. Region-wise, tear in rumen was significantly higher $(28.39 \mathrm{~N} \mathrm{~mm}-1)$ than in reticulum $(17.66 \mathrm{~N} \mathrm{~mm}-1)$ (Table 1$)$.

The values obtained in physicochemical tests of rumen and reticulum are showed in Table 
2. In treatment 1 , which used chrome salts, chrome oxide content observed in the samples was higher (3.5\%) compared to other treatments (Table 2).

Figure 3 shows a photomicrograph of rumen with different treatments (retanning with various tanning agents).
The rumen has type I collagen, which forms organized fibers and is thick as opposed to reticulum (Figure 4). In reticulum, fibers and fibrils can be seen (type III collagen).

Table 1. Test of resistance of rumen and reticulum for sheep

\begin{tabular}{|c|c|c|c|c|c|}
\hline Treatments & $\begin{array}{l}\text { Thickness } \\
\text { (mm) }\end{array}$ & $\begin{array}{c}\text { Maximum Force } \\
(\mathbf{N})\end{array}$ & 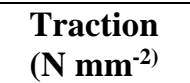 & $\begin{array}{c}\text { Elongation } \\
(\%)\end{array}$ & 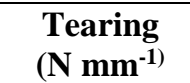 \\
\hline \multicolumn{6}{|l|}{ Retanning } \\
\hline Chrome salts & $0,85 \pm 0,35 b$ & $24,92 \pm 6,81 b$ & $3,47 \pm 1,14 \mathrm{a}$ & $92,76 \pm 22,66 a$ & $28,81 \pm 7,68 \mathrm{a}$ \\
\hline Vegetable tannin & $0,99 \pm 0,43 \mathrm{ab}$ & $24,50 \pm 8,25 b$ & $3,58 \pm 1,65 a$ & $68,44 \pm 23,46 b$ & $24,78 \pm 5,99 b$ \\
\hline Synthetic tannin & $1,25 \pm 0,47 a$ & $26,86 \pm 8,23 \mathrm{a}$ & $2,68 \pm 1,30 b$ & $76,06 \pm 18,73 \mathrm{ab}$ & $16,67 \pm 4,18 \mathrm{c}$ \\
\hline $\begin{array}{l}\text { Vegetable +Synthetic } \\
\text { tannin }\end{array}$ & $0,94 \pm 0,38 b$ & $25,66 \pm 9,29 a b$ & $3,19 \pm 1,41 \mathrm{ab}$ & $68,90 \pm 18,59 b$ & $24,11 \pm 8,96 b$ \\
\hline \multicolumn{6}{|l|}{ Regions } \\
\hline Rumen & $0,70 \pm 0,24 b$ & $23,27 \pm 7,56 b$ & $3,61 \pm 1,50 \mathrm{a}$ & $74,09 \pm 21,89 a$ & $28,39 \pm 6,34 a$ \\
\hline Reticulum & $1,32 \pm 0,41 \mathrm{a}$ & $29,69 \pm 7,85 a$ & $2,52 \pm 0,91 b$ & $76,78 \pm 23,64 a$ & $17,66 \pm 6,28 b$ \\
\hline
\end{tabular}

Means followed by the same lowercase letters in columns do not differ significantly by Tukey test $(\mathrm{P}>0.05)$.

Table 2. Mean values of physical-chemical tests of rumen and reticulum of sheep tanned with chrome and retanned with different tannins.

\begin{tabular}{|c|c|c|c|c|}
\hline Treataments & $\begin{array}{c}\text { Chrome Oxide } \mathrm{Cr}_{2} \mathrm{O}_{3} \\
(\%)\end{array}$ & $\begin{array}{c}\mathbf{p H} \\
\text { value }\end{array}$ & Difference figure & $\begin{array}{c}\text { Extractable substances with } \\
\text { Dichloromethane }(\%)\end{array}$ \\
\hline Chrome salts & 3,50 & 5,4 & $* * *$ & 34,2 \\
\hline Vegetable tannin & 1,3 & 5,4 & $* * *$ & 19,1 \\
\hline Synthetic tannin & 1,2 & 5,5 & $* * *$ & 24,4 \\
\hline $\begin{array}{l}\text { Vegetable +Synthetic } \\
\text { tannin }\end{array}$ & 1,2 & 5,5 & $* * *$ & 22,1 \\
\hline
\end{tabular}

\section{Discussion}

In tensile and elongation tests, the maximum applied force was higher for synthetic tannin $(26.86$ $\mathrm{N})$ retanning and combined tannin $(25,66 \mathrm{~N})$ retanning. However, retanning with combination of tannins did not differ from retanning with chrome $(24,92 \mathrm{~N})$ and vegetable $(24.50 \mathrm{~N})$ tannins. The maximum applied force was higher for reticulum $(29.69 \mathrm{~N})$, significantly different from rumen $(23.27 \mathrm{~N})$. This is due to the high thickness of this region, so there is a need to apply more force during the test.

Applying different retanning techniques to rumen and reticulum of cattle, Prado et al. (2015) reported that retanning with synthetic tannin and chrome resulted in higher traction resistance (2.13 $\mathrm{N} \mathrm{mm}-2$ and $2.05 \mathrm{~N} \mathrm{~mm}-2$, respectively) and progressive tearing $(21.03 \mathrm{~N} \mathrm{~mm}-1$ and $15.99 \mathrm{~N}$ $\mathrm{mm}-1$, respectively). Looking at different regions, rumen $(2.14 \mathrm{~N} \mathrm{~mm}-2,82.55 \%$ and $21.93 \mathrm{~N} \mathrm{~mm}-1)$ showed better results compared to reticulum. In this experiment, rumen also showed a better resistance compared to reticulum. As for the different retanning agents used in tanning, chrome salts and vegetable tannin provided the best results for sheep rumen and reticulum (Table 1).

Because of the lack of literature on rumen and reticulum strength tests, it is advisable that leather of different species of animals is assigned a strength parameter of this type in order to get a quality product used in clothing industry.

Souza et al. (2006) described that leather of rabbits retanned with chrome salts showed greater elasticity $(65.88 \%)$, significantly differing from that retanned with vegetable tannin, synthetic tannin and synthetic + vegetable tannins. In this experiment, rumen and reticulum retanned with chrome salts showed greater elasticity $(92.76 \%)$ compared to other treatments, despite not having deferred those retanned with synthetic tannin (76.06\%). However, the elasticity of sheep rumen and reticulum in this experiment was higher than those obtained for rabbit leather. It can be inferred that tanning agent is an important product in processing of hides, which determines the final characteristics of leather, and the same can be said 
of the raw material subjected to tanning process. In this case, rumen and reticulum had higher elasticity compared to rabbit leather. This can be attributed to distribution and orientation of collagen fibers.

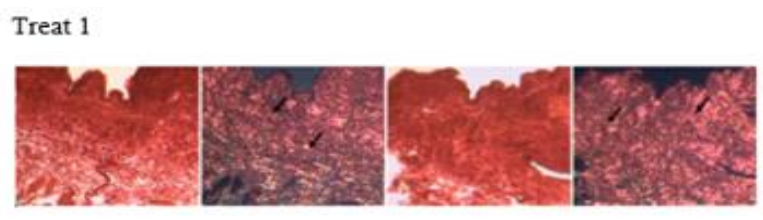

Treat 2

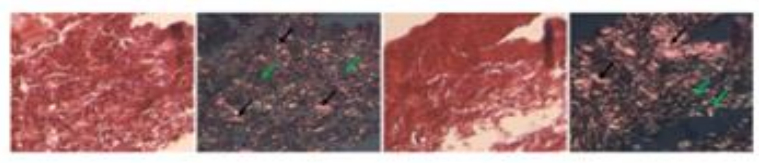

Treat 3

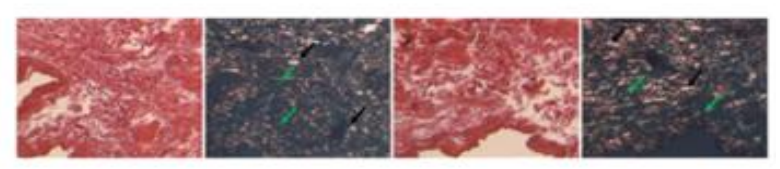

Treat 4

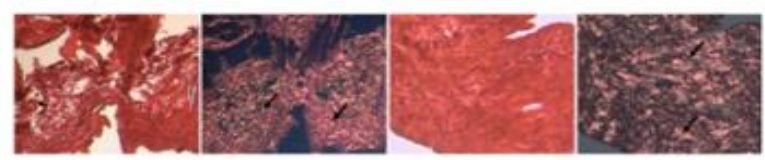

Figure 3. Photomicrography of sheep rumen showing collagen. Treat 1 - retanning with chrome salts; Treat 2 - retanning with vegetable tannins; Treat 3 - retanning with synthetic tannin, and; Treat 4 - retanning with synthetic + vegetable tannins. Black Arrow: type I collagen; Green Arrow: collagen type III. Picrossirius. 200x.

Treat 1

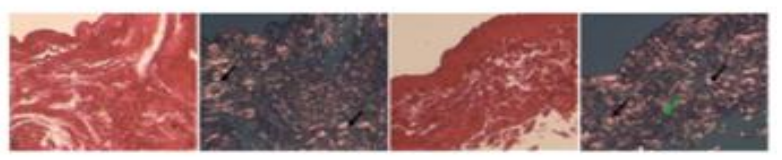

Treat 2

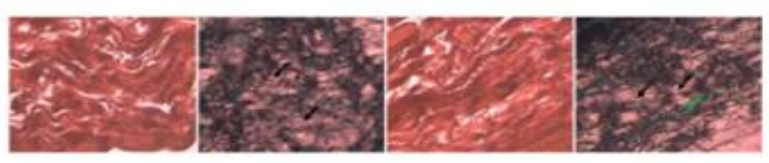

Treat 3

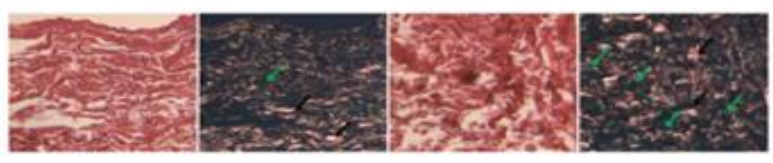

Treat 4

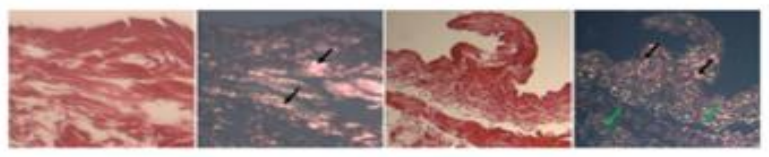

Figure 4. Photomicrography of sheep reticulum showing collagen. Treat 1 - retanning with chrome salts; Treat 2 - retanning with vegetable tannins; Treat 3 - retanning with synthetic tannin, and; Treat 4 retanning with synthetic + vegetable tannins. Black Arrow: type I collagen; Green Arrow: collagen type III. Picrossirius. 200x.
Rabbit leather showed superior traction resistance when vegetable tannin $(4.10 \mathrm{~N} \mathrm{~mm}-2)$ was used, compared to other treatments with different tanning agents (Souza et al., 2006). For bovine rumen and reticulum the lowest resistance value was obtained when using retanning with vegetable tannin (1.40 N mm-2), although it did not differ much from retanning with vegetable and synthetic tannin $(1.62 \mathrm{~N} \mathrm{~mm}-2)$. In this experiment, the obtained values for sheep rumen and reticulum were lower than those reported by Souza et al. (2006) for rabbit leather, but higher than those reported by Prado et al. (2015) for rumen-reticulum of cattle. The values obtained in progressive tearing test for rabbit leather were lower than those obtained in this experiment for rumen and reticulum; however, Souza et al. (2006) showed that progressive tearing was greater with the use chrome salts (16.37 N mm-1) were used, and in our tests the progressive tearing for rumen and reticulum was far superior when chrome salts $(28.81 \mathrm{~N} \mathrm{~mm}-1)$ were used.

The $\mathrm{pH}$ varied from 5.4 to 5.5 between treatments. This $\mathrm{pH}$ should have been around 3.5. In this $\mathrm{pH}$ range, it is best to fix used dyes and oils during the oiling stage (Table 2). For difference figure, as the $\mathrm{pH}$ values were high (above 5.0), there was no formation of free strong acids in the analyzed samples.

For substances extractable with Dichloromethane, i.e., the amount of fat in fixed parts, the values were in the range 19.1 to $34.2 \%$, with the largest percentage achieved when retanning with chrome salts (Table 2).

For chrome oxide, the results for rumen and reticulum are related to proportion of that tanning agent attached to collagen fibers. In his research Hoinacki (1989) found that the minimum value of chrome oxide in semi-finished leather must be $3.0 \%$. However, according to BASF (1995), chrome oxide value for leather must be above $2.5 \%$. Quantitative analysis of chrome oxide of rumen and reticulum retanned with chrome salts indicated that leather had the ability to withstand high temperatures and physical strength.

Substances which are soluble in dichloromethane are any substances that can be removed from sample by the solvent. This analysis is used to evaluate the content of oils and greases in leather. The content of substances extractable by dichloromethane should not be higher than $16 \%$ to $18 \%$ for leather to be used in clothing industry (BASF, 1995); rumen and reticulum retanned with 
chrome salts showed higher chrome oxide content and that of substances extractable by dichloromethane. Thus, chrome salts were more efficient in tanning and retanning of rumen and reticulum in treatment 1 , besides presenting higher content of oils. This is confirmed by chemical analyzes (Table 2).

Oiling substances (natural and synthetic oils in aqueous dispersions) are introduced into leather in a wet state and cover the surfaces of fibers and fibrils, providing these with a slippery quality and mobility (Hayes and Venkatraman, 2015). The main purpose of oiling process, which is basically the addition of oils, is to ensure softness of leather after drying and provide greater tearing resistance and traction.

Due to tanning process, leather $\mathrm{pH}$ usually shows traces of acid. Nonetheless, an excessive amount of acid inside leather can cause problems. The $\mathrm{pH}$ of aqueous extract from leather powder is determined by measuring the concentration of ions in the solution. Excessive acidity causes degradation of protein chain via acid hydrolysis, thus decreasing leather resistance (Jacinto et al. 2004). As reported by Hoinacki (1989), the minimum $\mathrm{pH}$ value in semi-finished leather must be 3.5 and difference figure must be of 0.7 at the most. In these samples rumen and reticulum $\mathrm{pH}$ values were much higher (5.4 and 5.5), because formic acid was absent at the time of fixation after oiling.

Flôres (1997) showed that physical and mechanical resistance of leather can be reduced, when the amount of acid is high (low $\mathrm{pH}$ ) due to the latter's corrosive effect on collagen fibers. The same author mentions that excess acid in leather structure, particularly sulfuric acid, affects fibers by slowly destroying them, leading to weak and brittle leather. In addition, there may be oxidation of metal components that come in contact with leather, such as rivets, buckles and eyelets, causing allergy or irritation in the user. The higher acid content in leather, the greater consequences it has on leather structure. Therefore, an adequate amount $(\mathrm{pH})$ and quality (differential code) of acids in leather should be determined.

In rumen and reticulum dyed with Picrosirius-Hematoxylin (PH) and analyzed using the polarization microscope, thicker collagen fiber bundles can be observed in rumen compared to reticulum. According to Junqueira et al. (1983), the thickness of collagen fibers play a major role in determining color wavelength in polarized sections dyed with Sirius Red. It is known that collagen molecules are rich in basic amino acids, reacting strongly with acidic dyes. The Sirius Red dye has long molecules and reacts with collagen, promoting an increase in birefringence due to the fact that many dye molecules are aligned in parallel with the long axis of collagen molecules. Increase in birefringence attained by using the Picrossirius polarization method is therefore specific to structures composed of collagen molecules. This method of analysis shows that fibers are composed of different types of collagens, such as type I and III, because the two have different interference and color intensity with birefringence within the same histological section.

Therefore, it can be concluded that rumen has more collagen fibers of type I, which are thicker and more organized, providing greater resistance. The result can be seen in Table 1: the rumen showed higher traction resistance $(3.61 \mathrm{~N}$ $\mathrm{mm}-2)$ and progressive tearing (28.39 $\mathrm{N} \mathrm{mm}-1)$. Thus, the results of physicomechanical tests can be linked to those obtained with histology, i.e. the strength of hardened product owes itself to histological structure of raw material which has been subjected to tanning.

\section{Conclusion}

Retanning with chrome salts adds tensile strength, elongation and progressive tearing to the material; retanning with synthetic tannin provides lower tensile strength and progressive tearing but results in a thicker final product.

Therefore, the best results were obtained with rumen retanned with chrome salts.

\section{Conflict of Interest}

The authors have not declared any conflict of interest.

\section{References}

ABNT. Associação Brasileira de Normas Técnicas. NBR 11041. Couro: determinação da resistência à tração e ao alongamento. Rio de Janeiro, 1997a.

ABNT. Associação Brasileira de Normas Técnicas. NBR 11030. Couro: determinação de substâncias extraíveis em diclorometano. Rio de Janeiro, 1997b.

ABNT. Associação Brasileira de Normas Técnicas. NBR 11034. Couro: preparação de amostras de couro para análise química. Rio de Janeiro, 2001. 
ABNT. Associação Brasileira de Normas Técnicas. NBR 11035. Couro: cortes de corpos de prova. Rio de Janeiro, 2005a.

ABNT. Associação Brasileira de Normas Técnicas. NBR 11055. Couro: determinação da força de rasgamento progressivo. Rio de Janeiro, 2005b.

ABNT. Associação Brasileira de Normas Técnicas. NBR 11057. Couro: determinação do pH e da cifra diferencial. Rio de Janeiro, 2006a.

ABNT. Associação Brasileira de Normas Técnicas. NBR 10455. Climatização de materiais usados na fabricação de calçados e correlatos. Rio de Janeiro, 2006b.

ABNT. Associação Brasileira de Normas Técnicas. NBR 11054. Couro: determinação de óxido crômico total. Rio de Janeiro, 2007.

Dal Monte, M.A.B.L.; Costa, R.G.; Jacinto, M.A.C.; Medeiros, A.N.; Figueiredo, F.C. Características físico-mecânicas e químicas do couro de caprinos abatidos em idades diferenciadas. Revista Brasileira de Zootecnia, 33(5):1285-1291. 2004.

Frandson, R.D.; Wilke, W.L.; Fails, A.D. Anatomia e Fisiologia dos Animais de Fazenda. 6a ed. Rio de Janeiro: Guanabara Koogan, 2005. 160p

Hayes, S.G.; Venkatraman, P. Materials and technology for sportswear and performance apparel. CRC Press, 2015, $343 p$.
Hoinacki, E. Peles e couros: origens, defeitos e industrialização. 2a ed. Porto Alegre: SENAI. 1989. $319 \mathrm{p}$.

Jacinto, M.A.C.; Sobrinho, A.G.S.; Costa, R.G. Características anátomo-estruturais da pele de ovinos (Ovis aries L.) lanados e deslanados, relacionados com o aspecto físico-mecânico do couro. Revista Brasileira de Zootecnia, 33(4):1001-1008 2004.

Jayathilakan, K.; Sultana, K.; Radhakrishna, K.; Bawa, A.S. Utilization of byproducts and waste materials from meat, poultry and fish processing industries: a review. Journal of food science and technology, 49:3: 278-293, 2012.

Junqueira, L.C.U., Joazeiro, P.P., Montes, G.S., Menezes, N., Pereira Filho, M. É possível o aproveitamento industrial da pele dos peixes de couro? Tecnicouro, 5(5):4-6, 1983.

Røssvoll, E.; Røtterud, O.J.; Hauge, S.J.; and Alvseike, O. A comparison of two evisceration methods on hygienic quality in the pelvic area of sheep carcasses." Meat science, 137: 134-138, 2018.

Prado, M.; Franco, M.L.R.S.; Machado, A.C.; Souza, E.D.; Uchimura, C.M.; Gasparino, E.; Del Vesco, A.P. Curtimento de rúmen e retículo de bovinos: qualidade de resistência. Acta Tecnológica, 10(1): 18-23, 2015.

SAEG. Sistemas de análises estatísticas e genéticas. Versão 8,0. Viçosa: Universidade Federal de Viçosa, 2000. 